\title{
ANALISIS ATTITUDES TOWARD CHEMISTRY (ATC) PADA MATERI KIMIA DASAR DENGAN PEMBELAJARAN DALAM JARINGAN (DARING)
}

\section{The Analysis of Attitudes Toward Chemistry (ATC) on General Chemistry Using Online Learning}

\author{
Nur Alawiyah*, Ulfa Lutfianasari \\ Program Studi Pendidikan Kimia Fakultas Sains dan teknologi \\ Universitas Islam Negeri Walisongo, Semarang \\ email: alawiyah@walisongo.ac.id
}

\begin{abstract}
Abstrak. Penelitian ini penting dilakukan karena sikap mahasiswa ketika pembelajaran dilakukan secara daring akan memberikan outcome yang berbeda. Tujuan dari penelitian ini adalah untuk mengetahui profil sikap mahasiswa kimia dan pendidikan kimia dalam mempelajari mata kuliah kimia dasar yang dilakukan secara daring. Ini merupakan penelitian kualitatif dimana data dihasilkan dari penyebaran Kuesioner yang diberikan kepada mahasiswa kimia dan pendidikan kimia, kemudian dilanjutkan dengan wawancara lebih lanjut terhadap subjek penelitian Data yang dihasilkan kemudian dianalisis dengan menghitung skor ratarata dari setiap item pertanyaan yang kemudian diprosentasikan. Hasil penelitian menunjukkan bahwa sikap mahasiswa kimia dan pendidikan kimia di UIN Walisongo Semarang masuk dalam kategori sangat baik. Pada indikator terkait dengan praktikum, mahasiswa cenderung kurang senang dengan praktikum yang dilakukan secara virtual melalui video. Sedangkan pada indikator terkait kebermanfaatan dan pentingnya mempelajari mata kuliah dasar menghasilkan skor tertinggi dari keempat indikator yang ada.
\end{abstract}

Kata kunci: analisis, Attitudes Toward Chemistry (ATC), kimia dasar, daring

\begin{abstract}
This research was important to do because the attitude of students when learning online would give different outcomes. The purpose of this study was to determine the attitude profile of chemistry and chemistry education students in studying general chemistry courses that were conducted online. This was a qualitative research where data was generated from the distribution of questionnaires given to chemistry and chemistry education students, then followed by further interviews with research subjects. The resulting data was analyzed by calculating the average score of each question item which was presented. The results showed that the attitude of chemistry students and chemistry education at UIN Walisongo Semarang was in the very good category. On indicators related to practicum, students tended to be less happy with practicum which was done virtually. Meanwhile, indicators related to the usefulness and importance of learning basic subjects resulted in the highest score of the four existing indicators.
\end{abstract}

Keywords: analysis, Attitudes Toward Chemistry (ATC), general chemistry, online 


\section{PENDAHULUAN}

Aspek Kognitif, Psikomotorik, dan Afektif merupakan tiga ranah yang menjadi objek penilaian dalam proses pembelajaran (Cheung, 2011). Attitude assessment atau penilaian sikap adalah aktivitas yang bersifat kompleks. Hal ini dikarenakan berkaitan dengan nilai dan obyeknya yang tidak langsung dapat diukur. Hasil penilaian sikap harus dipahami bukan merupaka hasil (output) yang instan dinilai oleh pendidik pada setiap kali menyelesaikan proses pembelajaran, akan tetapi sebagai proses (outcome). Kegunaan utama penilaian sikap sebagai bagian dari pembelajaran merupakan refleksi kemajuan sikap dan pemahaman mahasiswa secara individual (Prayitno, 2011).

Kegiatan evaluasi pada sikap mahasiswa penting dilakukan, karena reaksi positif atau negatif mahasiswa terhadap suatu mata kuliah dapat mempengaruhi minat belajar. Shaleh \& Wahab (2004:263) memberikan pengertian bahwa minat adalah suatu kecenderungan untuk memberikan perhatian dan bertindak terhadap orang, aktivitas atau situasi yang menjadi obyek dari minat tersebut dengan disertai perasaan senang. Mahasiswa akan semangat belajar tergantung pada sikap dan minat yang ada pada dirinya. Minat merupakan faktor psikologis yang berperan sebagai motivating force, yakni kekutatan yang akan menggerakkan seseorang untuk belajar (Riwahyudin, 2015). Oleh karena itu, membangun sikap positif dan tertarik pada sains merupkan salah satu kunci untuk kunci keberhasilan dalam proses pembelajaran sains (Hofstein \& Naaman, 2011). Pembelajaran sains yang difokuskan dalam penelitian ini adalah kegiatan belajar yang dilakukan secara online pada mata kuliah kimia dasar.

Mata kuliah kimia dasar sangat terkait antara penjelasan konsep dengan kegitan praktikum di laboratorium untuk menentukan keberhasilan dan kebermaknaan dari materi tersebut (Mariati \& Riska, 2012). Menurut Nufus, et. al., (2017) pembelajaran kimia tidak terlepas dari percobaan dan pengamatan yang memerlukan sikap tertentu, seperti tanggung jawab dan kejujuran dalam menganalisis data. Namun, sementara ini proses praktikum secara langsung di laboratorium tidak dapat dilakukan karena adanya pandemi Covid-19.

Pandemi COVID-19 (corona virus disease 2019) mulai ada di akhir tahun 2019 tepatnya di Wuhan, China. Kecepatan penyebaran merupakan salah satu karakteristik dari virus ini. Covid-19 dapat menyebar dengan cepat hingga ke lebih dari 200 negara hanya dalam tempo kurang dari 6 bulan tak terkecuali di Indonesia (World Health Organization, 2020). Adanya pandemi ini memberikan dampak dalam berbagai bidang, salah satunya adalah dalam bidang Pendidikan.

Kementerian Pendidikan dan Kebudayaan (Kemendikbud) menyatakan pelarangan pada perguruan tinggi untuk melakukan perkuliahan tatap muka (Surat Edaran Kemendikbud Dikti No. 1 tahun 2020) dan menghimbau perguruan tinggi untuk dapat menyelenggarakan pembelajaran secara daring atau online (Firman \& Rahayu, 2020). Menanggapi edaran tersebut, Perkuliahan harus diselenggarakan dengan konsep yang mampu mencegah berhubungan secara fisik antara mahasiswa dengan dosen maupun mahassiswa dengan mahasiswa, yakni melakukan pembelajaran dalam jaringan (daring). Pembelajaran daring merupakan sebuah kegiatan yang dilakukan dalam jarak jauh melalui media berupa internet dan alat penunjang lainnya seperti telepon seluler dan computer (Putria, et al., 2020).

Menurut sahu (2020) terdapat penurunan kualitas belajar pada mahasiswa karena situasi pandemi. Hal ini dikarenakan pembelajaran daring memiliki beberapa 
kekurangan. Beberapa kekurangan yang terjadi pada pembelajaran daring yaitu adanya kesulitan untuk fokus pada pembelajaran karena lingkungan dan suasana rumah yang kurang kondusif. Keterbatasan kuota internet, paket internet atau wifi yang menjadi penghubung dalam pembelajaran daring serta adanya ganguan dari beberapa hal lain. Sejalan dengan pemikiran Hadisi \& Muna (2015: 131) pembelajaran daring memberikan efek kurangnya interaksi antara dosen dan mahasiswa bahkan antar-mahasiswa itu sendiri. Kurangnya interaksi ini bisa memperlambat terbentuknya nilai dalam proses belajar mengajar.

Berdasarkan penjelasan di atas, penelitian ini penting dilakukan sebagai analisis dasar pemetaan sikap mahasiswa terhadap mata kuliah kimia dasar yang dilakukan secara online, dimana mata kuliah tersebut merupakan mata kuliah wajib yang harus diambil oleh mahasiswa kimia dan pendidikan kimia. Selain itu, penilaian sikap terhadap kimia ini juga akan menjadi dasar untuk pengembangan dan perbaikan kurikulum pembelajaran online pada periode selanjutnya.

\section{METODE PENELITIAN}

Jenis penelitian yang digunakan merupakan penelitian kualitatif. Penelitian dilakukan dengan menyebarkan kuesioner melalui google form yang berisi sebanyak dua belas pertanyaan mengenai Attitudes Toward Chemistry yang dikembangkan oleh Cheung (2011) dengan empat indikator, yakni (1) Liking for chemistry theory lessons, (2) Liking for chemistry laboratory work, (3) Evaluative beliefs about school chemistry, dan (4) Behavioral tendencies to learn chemistry. Subyek dari penelitian ini adalah mahasiswa kimia dan Pendidikan kimia yang mendapat mata kuliah teori dan praktikum kimia dasar selama masa pandemi Covid-19 di Univeristas Islam Negeri (UIN) Walisongo Semarang.

Hasil Kuesioner Attitudes Toward Chemistry dapat dicari dengan menghitung jumlah skor rata-rata dari setiap item pertanyaan yang kemudian dijadikan dalam bentuk persentase dengan menggunakan rumus;

$$
X \%=\frac{\Sigma S A}{\Sigma S I} \times 100 \%
$$

Dimana ESA merupakan jumlah Skor Aktual yang diperoleh dari jumlah hasil transformasi data Kuesioner dan ESI merupakan jumlah Skor Ideal yang diperoleh dari jumlah subjek atau sampel dikali dengan skor maksimal bobot Kuesioner.

Setelah dilakukan penyebaran Kuesioner dan kemudian hasilnya dianalisis, selanjutnya dilakukan wawancara secara mendalam kepada sepuluh subyek penelitian, lima yang memberikan skor tinggi dan lima yang memberikan skor rendah. Dasar pertanyaan wawancara lanjutan yakni sesuai dengan kondisi jawaban yang diberikan subyek penilitian pada kuesioner yang telah diberikan.

\section{HASIL PENELITIAN DAN PEMBAHASAN}

Penelitian dilakukan dengan terlebih dahulu menyusun instrumen berupa

Kuesioner. Kuesioner sikap terhadap kimia (Attitudes Toward Chemistry) dalam penelitian ini telah mengadopsi Kuesioner SATCL (Student Attitude Toward Chemistry 
Lesson) yang dikembangkan oleh Cheung (2011), kemudian di terjemahkan dan disesuaikan dengan kondisi pembelajaran yang dilaksanakan secara online atau daring. Kuesioner ini terdiri dari 12 pertanyaan dimana mewakili 4 indikator yang telah ditentukan seperti pada tabel 1 .

Kuesioner kemudian disebarkan kepada mahasiswa kimia dan pendidikan kimia yang telah mendapatkan materi kimia dasar I beserta praktikumnya dimana proses pembelajarannya dilakukan secara daring melalui google form. Sebanyak 42 responden yang telah mengisi Kuesioner. Hasilnya kemudian di analisis dengan mencari jumlah rerata dari per item pertanyaan yang kemudian diprosentasikan. Selanjutnya, analisis dilakukan pada tiap indikator dengan mencari jumlah rerata tiap indikator dan kemudian dilanjutkan dengan melakukan wawancara terhadap 10 subyek penelitian yang dipilih karena alasan tertentu (purposive sampling). purposive sampling merupakan teknik pengambilan sampel sumber data dengan pertimbangan tertentu (Sugiyono, 2016:85). Alasannya, tidak semua sampel memiliki kriteria yang sesuai dengan fenomena yang diteliti. Oleh karena itu, peneliti memilih teknik ini dengan menetapkan pertimbangan dan kriteria tertentu yang harus dipenuhi oleh sampel yang akan diwawancara.

Tabel 1. Indikator dan pertanyaan

\begin{tabular}{|c|c|}
\hline Indikator & Item Pertanyaan \\
\hline Liking for & P1. Saya menyukai mata kuliah kimia Dasar \\
\hline chemistry & P5. Pembelajaran kimia Dasar yang dilakukan \\
\hline theory & secara daring tetap menarik \\
\hline lessons & $\begin{array}{l}\text { P9. Kimia Dasar adalah salah satu mata kuliah } \\
\text { favorit saya }\end{array}$ \\
\hline Liking for & P2. Saya tetap senang melakukan eksperimen \\
\hline chemistry & kimia yang dilakukan secara virtual \\
\hline \multirow{3}{*}{$\begin{array}{l}\text { laboratory } \\
\text { work }\end{array}$} & P6. Ketika saya mengamati video praktikum kimia \\
\hline & $\begin{array}{l}\text { dasar, saya tetap merasa sedang melakukan } \\
\text { sesuatu yang sangat penting }\end{array}$ \\
\hline & $\begin{array}{l}\text { P10. Melakukan praktikum kimia Dasar secara } \\
\text { daring tetap menyenangkan }\end{array}$ \\
\hline Evaluative & P3. Mata kuliah Kimia Dasar bermanfaat untuk \\
\hline beliefs & menyelesaikan berbagai permasalahan sehari - \\
\hline about & hari \\
\hline school & P7. Orang -orang harus memahami kimia karena \\
\hline \multirow[t]{2}{*}{ chemistry } & kimia mempengaruhi kehidupan mereka \\
\hline & $\begin{array}{l}\text { P11. Kimia Dasar adalah salah satu mata kuliah } \\
\text { yang sangat penting untuk dipelajari di jurusan } \\
\text { kimia dan Pendidikan kimia }\end{array}$ \\
\hline $\begin{array}{l}\text { Behavioral } \\
\text { tendencies }\end{array}$ & $\begin{array}{l}\text { P4. Saya akan meluangkan waktu untuk membaca } \\
\text { buku -buku Kimia Dasar }\end{array}$ \\
\hline \multirow[t]{2}{*}{$\begin{array}{l}\text { to learn } \\
\text { chemistry }\end{array}$} & $\begin{array}{l}\text { P8. Saya senang menyelesaikan permasalahan - } \\
\text { permasalahan baru dalam ruang lingkup mata } \\
\text { kuliah dasar }\end{array}$ \\
\hline & $\begin{array}{l}\text { P12. Jika saya memiliki kesempatan, saya akan } \\
\text { melakukan proyek dalam lingkup mata kuliah } \\
\text { kimia dasar }\end{array}$ \\
\hline
\end{tabular}


Hasil penelitian menunjukkan bahwa persentase sikap mahasiswa terhadap kimia pada mata kuliah teori dan praktikum kimia dasar secara daring adalah sebesar 80,07\%. Hasil prosentase kemudian diinterpretasikan seuai dengan pengkategorian yang dilakukan oleh Jakni (2016:107). Hasil analisis yang menghasilkan 80,07\% masuk dalam kategori sangat baik sesuai dengan tabel 2. Hal ini dapat diartikan bahwa sikap mahasiswa kimia dan pendidikan kimia dapat menerima mata kuliah teori dan praktikum kimia dasar dengan senang hati meski dilakukan secara daring. Penerimaan dengan senang hati ini tentunya akan mempengaruhi hasil belajar dari mahasiswa tersebut. Menurut Riwahyudin (2015) Mahasiswa yang memiliki minat tinggi terhadap kegiatan belajar akan berusaha lebih keras dibandingkan mahasiswa yang kurang berminat, sehinga dapat pula mempengaruhi hasil belajarnya.

Tabel 2. Tolok Ukur Kategori Persentase Kuesioner

\begin{tabular}{cc}
\hline Persentase & Kategori \\
\hline $80,00-100,00$ & Sangat baik \\
$60,00-79,99$ & Baik \\
$40,00-59,99$ & Cukup \\
$00,00-39,99$ & Kurang \\
\hline
\end{tabular}

Jika dianalisis lebih lanjut pada tiap indikator, pada indikator Liking for chemistry laboratory work rata-ratanya paling rendah diantara yang lain sesuai dengan gambar 1. Hal ini dikarenakan mahasiswa kurang menyukai dengan diadakannya praktikum yang dilakukan secara virtual. Berdasarkan data wawancara lebih lanjut pada mahasiswa yang memberikan nilai rendah untuk indikator ini menjelaskan bahwa kurang tertarik terhadap praktikum virtual memlaui video. Hal ini karena mahasiswa tersebut tidak mendapat pengalaman secara langsung untuk melakukan konfirmasi dari teori mata kuliah kimia dasar yang diterima melalui praktikum. Ini sesuai dengan pernyataan Suharso $(2011,389)$, yakni tujuan diadakannya praktikum adalah agar mahasiswa dapat membuktikan kebenaran teori-terori yang ada.

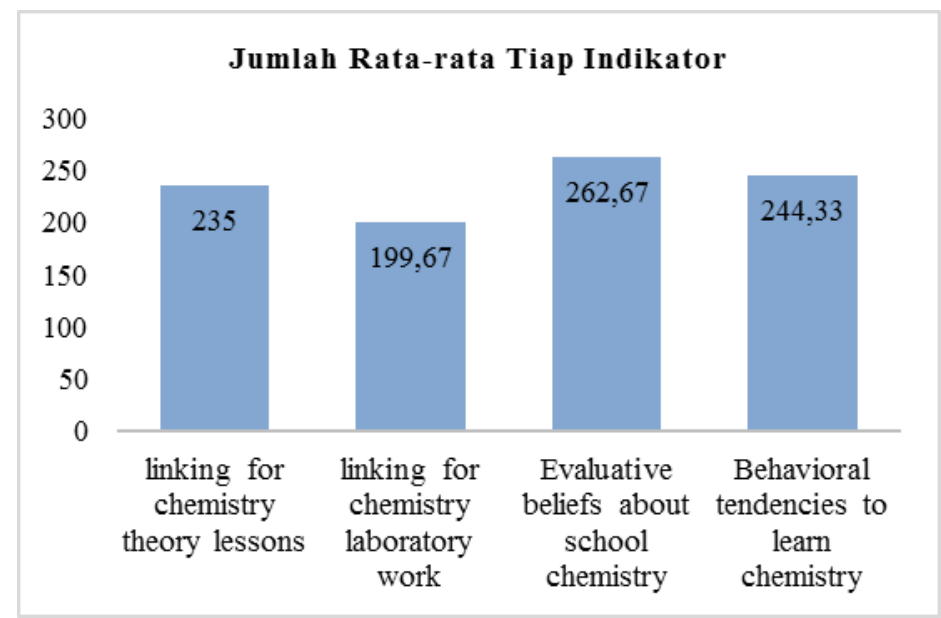

Gambar 1. Jumlah Rata-rata pada Setiap Indikator Attitudes Toward Chemistry 
Hal ini dikuatkan lagi oleh penelitian yang lakukan oleh Nisa (2017). Hasil penelitiannya menunjukkan bahwa kegiatan praktikum dapat meningkatkan pemahaman dan hasil belajar menjadi baik sampai pada $81,80 \%$. Jumlah rata-rata untuk indikator ke tiga, Evaluative beliefs about school chemistry memiliki nilai tertinggi. Hal ini dikarenakan tiga pertanyaan yang mewakili indikator ini adalah tentang kebermanfaatan mempelajari kimia. Mahasiswa memberikan nilai yang tinggi pada tiga petanyaan ini karena mereka memang fokus untuk mempelajari kimia dasar sesuai dengan prodi yang dipilih. Mereka pada dasarnya sudah memiliki ketertarikan terhadap materi kimia, sehingga mereka akan mengaggap penting terkait manfaat dari materi yang mereka pelajari. Ini sesuai dengan hasil wawancara lanjutan pada subyek penelitian yang memberikan nilai tinggi pada indikator ini. Ia menyatakan bahwa mata kuliah kimia dasar sangat penting dipelajari karena merupakan konsep dassar yang harus dipahami oleh mahasiswa kimia dan pendidikan kimia untuk digunakan sebagai bekal dalam mempelajari materi kimia lainnya. Ia juga merupakan salah satu pondasi dasar dalam ilmu sains, teknologi dan industri (Mahdi, 2014). Tak hanya itu, Bagi mahasiswa calon guru kimia, mata kuliah kimia dasar menjadi penting karena merupakan mata kuliah yang berkaitan dan dekat dengan konsep kimia yang dipelajari pada sekolah. Sehingga perlu kematangan pemahaman dalam mempelajarinya untuk menghindari miskonsepsi.

\section{SIMPULAN}

Simpulan yang diperoleh dari penelitian yang telah dilakukan adalah bahwa mahasiswa kimia dan pendidikan kimia UIN Walisongo Semarang memberikan sikap yang positif terhadap mata kuliah kimia dasar I baik pada teori maupun pada praktikum meskipun pembelajaran dilakukan secara online. Akan tetapi, pada mata praktikum, mahasiswa merasa kurang berminat jika dilakukan secara virtual. Ini dibuktikan dengan pemberian skor rendah pada indikator ke dua, yakni keterhubungan kimia dangan pekerjaan di laboratorium. Mahasiswa tersebut membutuhkan pengalaman langsung untuk melakukan percobaan kimia agar memperoleh kebermaknaan dalam praktikum yang dilakukan.

\section{DAFTAR RUJUKAN}

Cheung, D. (2009). Developing a Scale to Measure Students' Attitudes toward Chemistry Lessons. International Journal of Science Education. 31(16), 21852203.

Firman, F., \& Rahayu, S. (2020). Pembelajaran Online di Tengah Pandemi Covid19. Indonesian Journal of Educational Science (IJES). 2(2), 81-89.

Hadisi, L., \& Muna, W. (2015). Pengelolaan Teknologi Informasi dalam Menciptakan Model Inovasi Pembelajaran (E-Learning). Jurnal Al-Ta'dib, 8(1), 117-140.

Hofstein, A. \& Naaman, R. M. (2011). High-School Students' Attitudes Toward and Interest in Learning Chemistry. Educacion Quimica. 22 (2), 90-102.

Jakni. (2016). Metodologi Penelitian Eksperimen Bidang Pendidikan. Bandung: CV. Alfabeta

Mahdi, J. G. (2014). Student Attitudes Towards Chemistry: An Examination of Choices and Preferences. American Journal of Educational Research. 2 (6), 351-356. 
Dalton : Jurnal Pendidikan Kimia dan Ilmu Kimia, Volume 4 Nomor 1, Mei 2021

Mariati, M. R., \& Riska, C. N. (2012). Penerapan Model Apprentice Training yang Berwawasan Konstruktivisme dalam Upaya Meningkatkan Kualitas Pembelajaran Kimia. Jurnal Pendidikan Serambi Ilmu, 13(2), 66-69

Nisa, U. M,. (2017). Metode Praktikum untuk Meningkatkan Pemahaman dan Hasil Belajar Siswa Kelas V MI YPPI 1945 Babat pada Materi Zat Tunggal dan Campuran. Proceeding Biology Education Conference. 14 (1), 62-68.

Nufus, S. H., Gani, A., \& Suhendrayatna. (2017). Pengembangan Instrumen Penilaian Sikap Berbasis Kurikulum 2013 pada Pembelajaran Kimia SMA. Jurnal Pendidikan Sains Indonesia. 5 (1), 44-51

Prayitno, R. S. (2011). Penilaian Pendidikan Kimia. Malang: Jurusan Kimia FMIPA UM.

Putria, H., Maula, H.L., \& Uswatun, A. D. (2020). Analisis Proses Pembelajaran Dalam Jaringan (DARING) Masa Pandemi COVID-19 pada Guru Sekolah Dasar. Jurnal Basicedu. 4 (4), 861 - 872.

Riwahyudin, A. (2015). Pengaruh Sikap Siswa dan Minat Belajar Siswa Terhadap Hasil Belajar IPA Siswa Kelas v Sekolah Dasar di Kabupaten Lamandau. JPD: Jurnal Pendidikan Dasar. 6 (1), 11-23.

Sahu, P. (2020). Closure of Universities Due to Coronavirus Disease 2019 (COVID-19): Impact on Education and Mental Health of Students and Academic Staff. Cureus, 2019(April). https://doi.org/10.7759/cureus.7541.

Shaleh, A. R. \& Wahab, M. A. (2004). Psikologi. Jakarta: Prenada Media.

Sugiyono. (2016). Metode Penelitian Kuantitatif, Kualitatif dan R\&D. Bandung: PT Alfabet

Suharso. 2011. Kamus Besar Bahasa Indonesia. Semarang: Widya Karya.

World Health Organization. (2020). Coronavirus disease 2019 (COVID-19)Situation Report -71. https://www.who.int/docs/default-source/coronaviruse/situationreports/20200331-sitrep-71- covid-19.pdf?sfvrsn=4360e92b_8. 